\title{
ПРЕДПРИНИМАТЕЛЬСКАЯ ДЕЯТЕЛЬНОСТЬ КАК ОБЪЕКТ НАЛОГОВО-ПРАВОВОГО РЕГУЛИРОВАНИЯ (НА ПРИМЕРЕ СЕЛЬСКОХОЗЯЙСТВЕННЫХ ПРОИЗВОДИТЕЛЕЙ)
}

\begin{abstract}
BUSINESS ACTIVITY AS AN OBJECT
OF TAX AND LEGAL REGULATION
(ON THE EXAMPLE OF AGRICULTURAL
PRODUCERS)
N. Mamedov

Summary. It is a well-known fact that entrepreneurial activity plays an important role in human activity. Thus, according to article 34 of the Constitution of the Russian Federation, a citizen can use both his property and his abilities to carry out legitimate business activities. Modern society is guided by the fact that the implementation of entrepreneurial activity is carried out by subjects of civil law, which can act as both individuals (when registering themselves as an individual entrepreneur) and legal entities (organizations that are responsible for their own property). it is the tax practice of law enforcement that allows us to form a new view and new approaches to the development of measures to improve the effectiveness of the existing tax mechanism both in general and specifically in the field of taxation of small businesses in the agricultural sector. In particular, it requires the development of a modern approach to the legal regulation of legal relations in this area, the creation of an effective legal mechanism for taxation of small businesses, which should be considered as a separate legal institution, which is based on a comprehensive system of legal relations, involving not only tax, but also civil and a number of other relations. At the same time, the state policy in the field of agricultural production forces the state itself to solve urgent problems related to ensuring the strict receipt of tax payments. On the one hand, the state creates good conditions for the development of the potential of small businesses: an adequate regulatory framework is formed, the protection of their interests is guaranteed and preferential tax regimes are established. On the other hand, in order to increase budget revenues, the state should take special measures that can ensure the effective organization of taxation of these entities, including by tightening tax rules, introducing new tax control procedures, etc.
\end{abstract}

Keywords: activity, economy, profit, taxes, subject, object, entrepreneur, mechanism, budget, finance, law.

\author{
Мамедов Ниджат Джамиль Оглы \\ Аспирант, Саратовская Государственная \\ Юридическая Академия; старший преподаватель, \\ Санкт-Петербургский Государственный Университет \\ Аэрокосмического Приборостроения \\ nijat1984@yandex.ru
}

Аннотация. Известный факт, что предпринимательская деятельность играет важную роль в человеческой деятельности. Так, согласно статье 34 Конституции РФ гражданин может использовать как свое имущество, так и свои способности для осуществления законной предпринимательской деятельности. Современное общество ориентируется на то, что реализация предпринимательской деятельности осуществляется субъектами гражданского права, которые могут выступать в роли как физических (при оформлении себя как индивидуального предпринимателя), так и юридических лиц (организации, несущие ответственность за собственное имущество). именно налоговая практика правоприменения позволяет в целом сформировать новый взгляд и новые подходы к разработке мер повышения эффективности существующего механизма налогообложения как в целом, так и конкретно в сфере налогообложения субъектов малого предпринимательства в сельскохозяйственной сфере. В частности, требуется разработка современного подхода к правовому регулированию правоотношений в указанной сфере, созданию эффективного правового механизма налогообложения субъектов малого предпринимательства, который следует рассматривать в качестве отдельного правового института, в основу которого положена комплексная система правоотношений, предполагающая не только налоговые, но и гражданско-правовые и ряд иных отношений. При этом государственная политика в области сельскохозяйственного производства вынуждает само государство решать актуальные задачи, связанные с обеспечением неукоснительного поступления налоговых платежей. С одной стороны, государством создаются хорошие условия для развития потенциала малого предпринимательства: формируется адекватная нормативная база, гарантируется защита их интересов и устанавливаются льготные налоговые режимы. С другой стороны, с целью увеличения доходов бюджета государству надо предпринимать специальные меры, способные обеспечить эффективную организацию налогообложения указанных субъектов, в том числе посредством ужесточения правил налогообложения, введения новых процедур налогового контроля и т.д.

Ключевые слова: деятельность, хозяйства, прибыль, налоги, субъект, объект, предприниматель, механизм, бюджет, финансы, закон. 
$\Pi$ редпринимательская деятельность признается законодательством в качестве гражданско-правовой категории, закрепив ее понятие в п. 1 ст. 2 Гражданского кодекса РФ.

Там же обозначено, что предпринимательская деятельность является самостоятельным рискованным делом, которое направлено на получение законной финансовой прибыли, что позволяет выделить 4 главных направления данного вида деятельности:

- предпринимательская деятельность является делом волевым, самостоятельным;

- при занятии предпринимательской деятельностью имеются собственные риски и подразумевает получение доходов для собственных нужд;

- предпринимательская деятельность подразумевает получение доходов, что и выступает в качестве основной цели деятельности;

- предпринимательская деятельность должна быть зарегистрирована в государстве, а прибыль от нее подлежит налогообложению.

Фактически, критерий получения прибыли выступает как основной признак разграничения в п. 1 ст. 50 ГК РФ коммерческих и некоммерческих организаций.

Основная идея определения предпринимательства только как целенаправленной деятельности, связанной с извлечением прибыли легла в основание сформированной в 90-е гг. XX в. уже российской системы гражданского права при последующей детализации в иных положениях российского законодательства.

Результатом данных процессов явилось упрощенность понимания самой сути предпринимательской деятельности и системы критериев ее оценки различными группами населения России.

К особенностям юридического лица можно отнести:

- наличие иерархической структуры подчинения, управления, и взаимоотношения в рамках конкретной организации;

- наличие имущества в собственности;

- участники юридического лица не отвечают по обязательствам гражданско-правовой ответственности;

- самостоятельность в финансовом обороте, то есть юридическое лицо в праве осуществлять обязанности, приобретать необходимое от своего лица, также нести ответственность перед судом [1].

Одним из известных представителей субъектов предпринимательства выступают сельскохозяйственные производители, агропромышленные организации и фермерские частные хозяйства. Агропромышленное производство подразумевает под собой выращивание продукции для населения и оказание необходимых услуг в своей сфере. Сельскохозяйственными товаропроизводителями могут быть как физические, так и юридические лица. Они занимаются производством и переработкой агропромышленной продукции. Причем производимая продукция должна входить в перечень, установленный Правительством РФ.

Прибыль от производимой продукции должна составлять 75\% от всей поступающей прибыли в год [2] (в соответствии со ст. 3 Федерального закона № 264-Ф3 от 29 дек. 2006 г. «О развитии сельского хозяйства»).

Особое место в предпринимательской деятельности занимают крестьянские (фермерские) хозяйства. В 2013 году появилась статья 86.1 в Гражданском Кодексе РФ о положении фермерских хозяйств, согласно которой крестьянское хозяйство из индивидуального предпринимателя приобрело статус юридического лица, что подразумевает под собой объединение лиц с целью производства продукции и извлечения прибыли от ее реализации посредством совместного объединения имущества и усилий, что подкрепилось нормами федерального законодательства[3].

Особое внимание следует уделить такой структуре, как сельскохозяйственный кооператив, которые бывают потребительскими либо производственными, соответственно, также они могут быть как коммерческими, так и некоммерческими. При любой форме эти юридические организации создаются сельхозпроизводителями и (или) ведущими личные подсобные хозяйства гражданами [4].

Очевидно, что агропромышленным организациям необходимо юридическое оформление. Работники сельскохозяйственной предпринимательской деятельности должны применять свой собственных труд для получения продуктов производства, из реализации и получения прибыли. В сельском хозяйстве достаточно часто можно встретить как акционерные общества, так и общества с ограниченной ответственностью.

К главной особенности сельскохозяйственной предпринимательской деятельности следует отнести наличие при ее осуществлении такого главного средства производства как земли сельскохозяйственного назначения.

Правовой режим как использования, так и обращения земель сельскохозяйственного назначения регламентируется, прежде всего, актами земельного законодательства (Земельный кодекс РФ и ФЗ «Об обороте земель сельскохозяйственного назначения»). 
К составу земель сельскохозяйственного назначения отнесены земли, которые находятся за границами населенного пункта, они должны быть не только предоставлены для нужд сельскохозяйственного производства, но также предназначены для этих целей.

Подобные требования при определении земель сельскохозяйственного назначения содержатся в ст. 77 Земельного кодекса РФ от 25 октября 2001 г. № 136-Ф3 (далее - ЗК РФ) [5]. В составе земель сельскохозяйственного назначения находятся сельскохозяйственные угодья, которыми на основании ст. 79 ЗК РФ признаны пашни, пастбища, сенокосы, виноградники, сады, залежи, а также земли, занимаемые:

- дорогами, коммуникациями, лесами;

- водными объектами;

- сооружениями, предназначенными для выращивания, хранения и переработки агропромышленной продукции.

В силу п. 1 ст. 78 ЗК РФ земли сельскохозяйственного назначения могут быть использованы для решения задач, связанных с ведением сельскохозяйственного производства, созданием защитных лесных участков, научно-исследовательскими задачами в области сельской промышленности, а также для целей рыбоводства определенными в законодательстве субъектами.

Таковыми выделяются ряд категорий, а именно:

- «крестьянские (фермерские) хозяйства - для осуществления их деятельности, а также граждане, ведущие личное подсобное хозяйство, садоводство, огородничество или животноводство;

- хозяйственные товарищества, унитарные организации, иные коммерческие предприятия;

- некоммерческие организации (потребительские кооперативы, религиозные организации);

- казачьи общества;

- производственные, учебно-опытные и учебно-производственные подразделения научных организаций или образовательных организаций;

- общины коренных малочисленных народов Сибири, Севера и Дальнего Востока России с целью сохранения и развития их образа жизни, хозяйствования и промыслов.

Также необходимо подчеркнуть, что земельные участки (которые отнесены к почве агропромышленного назначения), установлены в налоговом законодательстве в качестве объекта налогообложения по земельному налогу. Это вытекает из положений ст. 389 Налогового кодекса РФ.

Суммы земельного налога налогоплательщиками - организациями и физическими лицами, за- регистрированными в качестве индивидуальных предпринимателей, исчисляются самостоятельно по истечении налогового периода, каким признается календарный год. Это установлено в п. 1 ст. 393 НК РФ, п.п. 1, 2 ст. 396 НК РФ. В случае же налогоплательщиков - физических лиц, которые не являются индивидуальными предпринимателями,- для них сумма земельного налога определяется налоговым органом (п. 3 ст. 396 НК РФ).

Активное участие государства в повышении эффективности налогообложения сельскохозяйственных товаропроизводителей во многом обусловлено наличием у него возможности прямого регулирования условий осуществления этой деятельности, а также необходимость поддержки сельскохозяйственных товаропроизводителей, осуществляющих не настолько прибыльный вид хозяйственной деятельности.

Во многом это находит свое отражение в разработке и реализации эффективной налоговой политики, позволяющей решать проблему финансовой поддержки и развития в целом агропромышленного комплекса и отдельных его элементов.

Одним из основных направлений налоговой политики как раз и выступает модернизация системы налоговых преференций и льготы, которое, в том числе позволяет и привлекать инвестиций в различные отрасли сельскохозяйственного производства.

Развитие сельскохозяйственного производства в большинстве государств мира отнесено к разряду национальных приоритетов. Это позволяет на национальном уровне осуществлять перераспределение финансовых ресурсов посредством налогового регулирования при осуществлении активной политики бюджетной поддержки в форме субсидирования. Кроме того, для роста сельскохозяйственного производства достаточно активно сельскохозяйственными товаропроизводителями используются и пониженные ставки прямых налогов.

В настоящее время при осуществлении сельскохозяйственной предпринимательской деятельности ее субъекты подпадают под следующие действующие режимы налогообложения:

- общая система налогообложения. Ей соответствует необходимость уплаты общеустановленный налогов в случаях наличия соответствующих объектов налогообложения, в том числе налог на прибыль организаций и НДС. Данная система распространяется на все организации, которые не соответствуют статусу сельскохозяйственного товаропроизводителя; 
- единый сельскохозяйственный налог. К полученным доходам, которые уменьшены на величину расходов должна применяться ставка 6\%, а также освобождение от налогов на дополнительные наценки, на имущества и на доходы предприятий. Данный режим распространяется в отношении сельскохозяйственных товаропроизводителей или рыбохозяйственных организаций;

- упрощенная система налогообложения. В еe рамках происходит налогообложение полной прибыли, рассчитанный через кассу, и такой налог составляет 6\%. В рамках этого режима налогоплательщик получает освобождение от налогов: на дополнительные наценки, на имущества и на доходы предприятий. При применении режима «доходы, уменьшенные на величину расходов», применению подлежит ставка 15\% при аналогичном освобождении от налогов на дополнительные наценки, на имущества и на доход предприятий;

- патентная система налогообложения. Применяется ставка 6\% по базовой доходности в рамках осуществления отдельных видов деятельности при освобождении от налогов на дополнительную наценку, на имущества и на доходы предприятий. Данный режим действует только в отношении индивидуальных предпринимателей.

Государственное регулирование агропромышленного комплекса налоговыми инструментами может способствовать повышению качества жизни сельского населения. В этой связи налоговые льготы предполагают поддержку малых семейных сельхозпроизводителей.

\section{ЛИТЕРАТУРА}

1. Джигкаева Ф.З. Понятие и субъекты предпринимательской деятельности // Пробелы в российском законодательстве. 2010. № 3. С. 106.

2. Федеральный закон от 29 дек. 2006 г. № 264-Ф3 «0 развитии сельского хозяйства» // С РФ. — 2007. — № 1 (часть I). — Ст. 27.

3. Федеральный закон от 11 июня 2003 г. № 74-Ф3 «0 крестьянском (фермерском) хозяйстве» // СЗ РФ.— 2003.— № 24.— Ст. 2249.

4. Федеральный закон от 8 дек. 1995 г. № 193-Ф3 «0 сельскохозяйственной кооперации» // СЗ РФ.— 1995.— № 5.— — С. 4870.

5. http://www.consultant.ru/document/cons_doc_LAW_33773/ 